\title{
Moderating Role of Size in the Effect of Loan to Deposit Ratio and Non Performing Loan toward Banking Financial Performance
}

\author{
Ira Hapsari \\ Universitas Muhammadiyah Purwokerto \\ Irahapsari.ump@gmail.com
}

\begin{abstract}
. this research is proposed to measure the effect of Loan to Deposit Ratio and Non Performing Loans Ratio toward Financial performance proxied by Return On Assets (ROA) with Size as a moderating variable. The population in this research are commercial banking in Indonesia during 20122016 periods. Samples were taken by purposive sampling method and obtained 65 data from 13 banks of Business Group Commercial Banking Bank (BUKU) 3 and 4. Moderating Regression Analysis with absolute difference method was used to examine the research. The result showed that Loan to Deposit Ratio has a positive effect toward financial performance, Non Performing Loan has negative effect toward financial performance, while Size is not moderating both the effect of Loan to Deposit and Non Performing Loan toward financial performance.
\end{abstract}

Keywords: Loan to Deposit Ratio, Non Performing Loan Ratio, Size, Return on Asset

\section{INTRODUCTION}

Indonesia is categorized as a bank based country since this sector plays a vital role for the Indonesian Financial system [1]. In 2015, Indonesia entered ASEAN Economic Community (AEC) era where all ASEAN member countries agreed on ASEAN economic integration in facing ASEAN's Free Trade. This policy encouraged Indonesia to achieve strong economic progress and stability for facing wider global competition.

Two major activities of a bank is gathered funds from society in deposits and saving forms then give them back to the society in loans form. Bank should be able to balance the amount of deposits with given loans (credits). Loan to Deposit Ratio (LDR) states how far the ability of banks to repay the withdrawals made by depositors relying on the loans advantage given as a source of liquidity [2]. The bank profits derived from the margin the difference between the interest on credit and deposit interest savings and time deposits). Research conducted by [3] - [5] stated that the LDR affects the profitability of the company, while [6] - [7] stated that LDR has no effect on the company's financial performance
On credit process, it is possible to banks to face the risk of loans that are not paid by the debtor. The nonperforming bad debts rate is named Non-Performing Loan (NPL). The magnitude of the percentage of NPL should be particular concern because it reflects the bank's health and profitability. The higher the NPL, the lower the profitability, and vice versa. [3],[8] stated that NPLs negatively affects the financial performance of the company. On the other hand, [9] stated that the profitability of the company is not affected by NPL, and [10] stated that NPL has no effect and predict bank health and sustainability.

Company size can be seen from how much assets owned by a company. Size assures capital reserves, in order to keep the company's operations running, and it does not affect the trust of stakeholders. [11] stated larger banks are more profitable than smaller banks. Size is not studied as an independent variable but takes a moderating role for measuring performance.

The most considerable ratio in the financial statements is Return on Assets (ROA). ROA is a company's financial ratio related to profitability which this ratio measured the ability of a company to generate profits or earnings at the level of income, assets and capital stock. ROA reflects the ability of bank management in manages its assets to generate a profit [13]. By knowing ROA's value, we can assess whether the company has been efficient in optimizing its assets. The existing Research Gap draws the attention of researchers to further investigate the effect of LDR and NPL on the Company's financial performance, with one additional variable, Size that serves as a moderating variable, not as direct variable, but to assess whether Size moderates the effect of LDR and NPL variables toward financial performance proxied by ROA. We create the hyothesis as follows:

$\mathrm{H}_{1}$ : LDR has a positive effect toward financial performance

$\mathrm{H}_{2}$ : NPL has a negative effect toward financial performance

$\mathrm{H}_{3}$ : Size moderating the effect of LDR toward financial performance

$\mathrm{H}_{4}$ : Size moderating the effect of NPL toward financial performance 


\section{METHOD}

This research is considered as descriptive and quantitative research type. Sample was taken by non purposive sampling method from population of 116 commercial banks in Indonesia with the following criteria: i) Listed in IDX and continuously published their financial reports during 2012-2016 periods; ii) Banks included in Business Group Commercial Banking Bank (BUKU) 3 and 4 based on Bank Indonesia Regulation per January $1^{\text {st }} 2013$; iii) banks had no negative profit during research period. Secondary data were taken from five years annual financial reports of each bank listed in Indonesia Stock Exchange, while additional relevant information from bank official sites and other literatures. There were 13 banks, consist of five banks of BUKU 4 and eighth banks of BUKU 3 fulfilled the qualification with total 65 observations data.

Loan to Deposit Ratio (LDR) shows the amount of loans granted by banks to the ability of banks to repay the withdrawal of funds by depositors relying on loans provided as a source of liquidity [14]. LDR is measured by comparing total loans with total third party funds.

NPL is a part of non-performing loans [14], describes how much the ratio of non performing loans to the total amount of loans granted in a bank. NPL is measured by comparing total net Non Performing Loans with total Loans.

Size shows how big or small company size identification. Larger companies do larger activities. Size is measured by using the total asset.

The financial performance showed how good a company's ability to make a profit. It is shown by profitability ratio which is Return on Assets (ROA) ratio. ROA is measured by comparing profit before tax with total assets of the company.

Moderating Regression Analysis used absolute difference method in order to examined the research model and hypotheses with SPSS (Statistical Package for Social Science) application [15]. Acceptance criteria for six hypotheses were:

$\mathrm{H}_{\mathrm{a}}$ accepted if sig value $(\alpha) \leq 0.05$

$\mathrm{H}_{\mathrm{a}}$ rejected if $\operatorname{sig}$ value $(\alpha)>0.05$

\section{RESULT}

Several analysis steps are taken in this research, were:

a. Classical Assumption Test

The classical assumption test results shown that data have normal distributed residual values, no correlation between independent variables; there is a similarity of variance from one observation to another (homoscedasticity), and no correlation between observations in each different observation period.

b. Regression Test by Moderating Variable

Based on Table 1 in Adjusted R Square column, the determination coefficient value $\left(\mathrm{R}^{2}\right)$ is 0.443 or $44.3 \%$ indicates that ROA variable can be explained by LDR NPL and size while the remaining 0.557 or $55.7 \%$ is explained by other factors is not mentioned and tested in this study.

Table 1: Coefficient Determination Test Result

\begin{tabular}{lllll} 
Model Summary & & & \\
\hline Model & $\mathrm{R}$ & R Square & $\begin{array}{l}\text { Adj } \\
\text { usted R } \\
\text { Square }\end{array}$ & $\begin{array}{l}\text { Std. } \\
\text { Error of } \\
\text { the } \\
\text { Estimate }\end{array}$ \\
\hline 1 & $0.698^{\mathrm{a}}$ & 0.487 & 0.443 & \multicolumn{2}{c}{0.61} \\
\hline \multicolumn{2}{l}{ Source : content analysis, 2017} & &
\end{tabular}

Table 2: Hypothesis Test Result

\begin{tabular}{|c|c|c|c|c|c|}
\hline Variab & $\begin{array}{l}\text { Hypothe } \\
\text { tical } \\
\text { Direction }\end{array}$ & B & $\begin{array}{r}\mathrm{t}- \\
\text { count }\end{array}$ & $\begin{array}{r}P \\
\text { value }\end{array}$ & Conclusi \\
\hline LDR & + & $263^{0}$ & 3.0 & $003^{0 .}$ & Accepted \\
\hline NPL & - & 0.271 & 2.687 & $009^{0 .}$ & Accepted \\
\hline Size & + & $.328^{0}$ & $22^{2.6}$ & $011^{0 .}$ & $\begin{array}{l}\text { Unhypot } \\
\text { hized }\end{array}$ \\
\hline $\begin{array}{l}\text { Moder } \\
\text { ating size } \\
\text { in LDR }\end{array}$ & + & $\begin{array}{l}0 \\
.060^{0}\end{array}$ & $42 \quad$ & $660^{0 .}$ & $\begin{array}{c}\text { Not } \\
\text { Accepted }\end{array}$ \\
\hline $\begin{array}{l}\text { Moder } \\
\text { ating size } \\
\text { in NPL }\end{array}$ & - & 0.059 & 0.523 & $603^{0 .}$ & $\begin{array}{c}\text { Not } \\
\text { Accepted }\end{array}$ \\
\hline
\end{tabular}

Dependent Variable : ROA

Source : content analysis, 2017

Based on table 2 above is known that LDR coefficient is 0.263 with a positive direction and significance level is $0.003 \leq 0.05$. This means that $\mathrm{H}_{0}$ is rejected and $\mathrm{H}_{\mathrm{a}}$ is accepted then the first hypothesis which stated LDR has a positive effect toward financial performance is accepted. These results can be concluded that LDR positively affects the financial performance. LDR can be used as vulnerability or succeed indicator of a bank to balance its withdrawals and loans, because the banks profit derived from the margin between given loan's interest and deposit's interest. This result is along with the study done by [3]-[5],[16] stated that LDR has positive effect toward ROA while this result contradicts with the research conducted by [6]-[7],[17] stated that LDR has no effect toward ROA and financial performance.

The coefficient variable of NPL is $-0,271$ with negative direction and its significance level is $0.009 \leq$ 0,05 , this means that $\mathrm{H}_{0}$ is rejected and $\mathrm{H}_{\mathrm{a}}$ is accepted, then the second hypothesis which stated NPL has a negative effect toward financial performance is accepted. NPL affects banks' profitability adversely because of the provision of classified loans and consequent write-off as bad debts reduce the return on investment and disturb the capital adequacy ratio [18]. It also increases the cost of capital, widens assets and liability imbalance and upsets the economic value additions 1 by banks.[3],[8], [19] stated that NPLs negatively affect the financial performance of the company. But this result is contrary with the research 
conducted by [9] stated that NPL does not affect the profitability of the company, and [10] stated that NPL has no effect and predict bank health and sustainability.

The coefficient variable of size as a moderating variable in the effect of LDR toward finacial performance is 0.060 and its significance level is $0.660>$ 0,05 , this means that $\mathrm{H}_{0}$ is accepted and $\mathrm{H}_{\mathrm{a}}$ is rejected, then the third hypothesis which stated size moderating the effect of LDR toward financial performance is rejected.

The coefficient variable of size as a moderating variable in the effect of NPL toward finacial performance is -0.059 and its significance level is $0.603>0,05$, this means that $\mathrm{H}_{0}$ is accepted and $\mathrm{H}_{\mathrm{a}}$ is rejected, then the forth hypothesis which stated size moderating the effect of NPL toward financial performance is rejected.

From those moderating analysis can be found that size variable does not moderate them but it has a positive direct effect toward financial performance just as stated from previous research by [11],[18]-[20]. This finding contradicts with [12] and [21] researches which stated that size took as a moderating variable on financial performance.

\section{CONCLUSION}

From this research objectives, the result showed that Loan to Deposit Ratio positively affects financial performance and Non Performing Loan negatively affects financial performance. Size does not moderate the effect of Loan to Deposit Ratio and Non Performing Loan toward financial performance. This result may contribute in enriching literatures and digging more information related with financial performance issues and its driving factors. Related to this finding, management needs to run with free trade era by empowers its own resources, so it hopefully can create value added of the bank, thus it will elevate financial performance. This study also still has a limitation because it tested the effect Return On Assets ratio only. The next research can be objected to other ratios of profitability performance, such as Return On Equity, Return On Investment, Growth Ratio, Earning Per Share and other Business Group Commercial Banking (1 and 2). They might give different results so it is wider our point of view about these issues

\section{REFERENCES}

[1] R.Levine, "Bank Based or Market Base Financial System: Which is better. Journal of Financial Intermediation," Vol 11(Issue 4), 398-428, 2002.

[2] Sianturi, M.R. Rosari, "Pengaruh CAR, NPL, LDR, NIM, Dan BOPO Terhadap Profitabilitas Perbankan (Studi Kasus Pada Bank Umum Yang Listed Di Bursa Efek Indonesia Tahun 20072011)," Skripsi Jurusan Manajemen Pada Fakultas Ekonomi Dan Bisnis Universitas Hasanudin, Makasar, 2012.

[3] R Septiani,., \& P. V. Lestari, , "Pengaruh NPL dan
LDR terhadap Profitabilitas Dengan CAR sebagai Variabel Mediasi Pada PT BPR PASARRAYA KUTA. E-Jurnal Manajemen Unud, 5(1), 293-324, 2016.

[4] P. Brock, , \& L. R. Suarez,. "Understanding the behavior of interest rates and bank spread in Latin America" Working Paper (PUC-NBER) Conference, 63, 113-115, 1998.

[5] R.Agustiningrum, "Analisis pengaruh CAR, NPL, dan LDR terhadap profitabilitas pada Perusahaan Perbankan," E-Jurnal Manajemen Universitas Udayana, 885-902, 2011.

[6] Suminar., "Analisis Pengaruh CAR, NPL dan LDR Terhadap ROA pada Bank BUMN yang Terdaftar di Bursa Efek Indonesia (BEI) Periode 2009-2013," Jurnal Manajemen Branchmark ISSN : 2407-8239, 2015.

[7] Hantono, "Effect of capital adequacy ratio (CAR), Loan to Deposit Ratio (LDR) and Non Performing Loan (NPLl) to Return on Assets (ROA) listed in banking in indonesia stock exchange.," International Journal of Education and Research, 5(1), 69-80, 2017.

[8] I. B. P. A. K. Manuaba, "Pengaruh Capital Adequacy Rate, Non Performing Loan, Ukuran Perusahaan, dan Struktur Kepemilikan Terhadap Profitabilitas," E-Jurnal Akuntansi Universitas Udayana, 1(1)., 1-17. 2011.

[9] A. B Nusantara. , "ANALISIS PENGARUH NPL, CAR, LDR, DAN BOPO TERHADAP PROFITABILITAS BANK (Perbandingan Bank Umum Go Publik dan Bank Umum Non Go Publik di Indonesia Periode Tahun 2005-2007)," Semarang , Universitas Diponogoro, 1-31, 2009.

[10] S. Handayani, "Analisis Pengaruh CAMEL yang Dimoderasi Oleh Size Terhadap Tingkat Kesehatan Bank Daerah ( Studi Pada Pd . Bank Daerah Provinsi Jawa Timur Yang Terdaftar Di Bank Indonesia," Penelitian Ekonomi Dan Akuntansi, I(2), 95-110, 2016.

[11] A. Rauch, J.Wiklund, , G.T. Lumpkin, , M.Frese, , "Entrepreneurial Orientation and Business Performance: An assessment of past research and suggestions for the future. Entrepreneurship Theory and Practice," 33(3), 761-787, 2009.

[12] B. P. Banik, , \& P. C. Das, "Comparison of Financial Performance of State Owned Commercial Banks: A Case Study of Bangladesh," International Journal of Scientific Engineering and Research (IJSER), 1(1-3), 423-428. Retrieved from www.ijser.in, 2013.

[13] A. Dietrich, \& G. Wanzenried, "What determines the profitability of commercial banks? New evidence from Switzerland What determines the profitability of commercial banks? New evidence from Switzerland," Institute of Financial Services IFZ, Lucerne University of Applied Sciences, (March), 2-39. https://doi.org/EFM Classification: 510; 180; 150; 560, 2009. 
[14] W. Sugiarti, "Analisis Kinerja Keuangan dan Prediksi TingkatKesehatan Bank dengan Menggunakan Metode CAMEL pada Bank Umum yangTercatat di Bursa Efek Indonesia”, Jurnal Akuntansi , Fakultas Ekonomi Universitas Gunadarma, Jakarta, 2012.

[15] Suliyanto.2011. Ekonomika Terapan : Teori dan Aplikasi dengan SPSS.Penerbit Andi : Yogyakarta

[16] Mus, A. R., Mas, M., \& Su, M., "Effect of Ownership Concentration, Loan to Deposit Ratio and Non-Performing Loans toward Return on Equity and Stock Price Index of Banking Industry in Indonesia Stock Exchange," Australian Journal of Basic and Applied Sciences, 9(July), 666-671, 2015.

[17] P. Soares, \& M. Yunanto, "The Effect of NPL, CAR, LDR, OER and NIM to Banking Return on Asset," International Journal of Economics, Commerce and Management, VI(3), 40-55, 2018.
[18] S. Akhter \& J. Kumar, "Analysis of Credit Risk , Efficiency, Liquidity, and Profitability of Selected Non-Bank Financial Institution: An Empirical Study" Journal of Business, 02(02), 16-23, 2017.

[19] L. M. Chege \& J.Bichanga, "Non-Performing Loans and Financial Performance of Banks: An Empirical Study of Commercial Banks in Kenya," Journal of Management and Commerce Innovations ISSN 2348-7585, 4(2), 909-916, 2017.

[20] A. Waleed, M. B. Shah, \& M. K. Mughal, "Comparison of Private and Public Banks Performance," IOSR Journal of Business and ManagementVer. III, 17(7), 2319-7668. https://doi.org/10.9790/487X-17733238, 2015.

[21] A. Abbasi \& Q.A. Malik, "Firms Size Moderating Financial Performance in Growing Firms: An Empirical Evidence from Pakistan," International Journal of Economics and Financial Issues, 2015, 5(2), 334-339, 2015. 